\title{
Review
}

\section{Virus sensing receptors in cellular infectivity of influenza A virus}

\author{
Shaihana Almatrrouk¹, Iram Saba², Suhair M Abozaid², Ahmed A Al-Qahtani',3, Mohammed N Al- \\ Ahdal $2,3,4$ \\ ${ }^{1}$ Molecular Virology Section, National Health Laboratory, Ministry of Health, Riyadh, Saudi Arabia \\ ${ }^{2}$ Department of Infection and Immunity, King Faisal Specialist Hospital and Research Centre, Riyadh, Saudi Arabia \\ ${ }^{3}$ Department of Microbiology and Immunology, College of Medicine, Alfaisal University, Riyadh, Saudi Arabia \\ ${ }^{4}$ Department of Pathology and Laboratory Medicine, King Faisal Specialist Hospital and Research Centre, Riyadh, \\ Saudi Arabia
}

\begin{abstract}
An innate immune response is essential to mobilize protective immunity upon the infection of respiratory epithelial cells with influenza A virus (IAV). The response is classified as early (nonspecific effectors), local systematic (effector cells recruitment) and late (antigen to lymphoid organ transport, naive B and $\mathrm{T}$ cells recognition, effector cells clonal expansion and differentiation). Virus particles are detected by the host cells as non-self by various sensors that are present on the cell surface, endosomes and cytosol. These sensors are collectively termed as pattern recognition receptors (PRRs). The PRRs distinguish unique molecular signatures known as pathogen-associated molecular pattern, which are present either on the cell surface or within intracellular compartments. PRRs have been classified into five major groups: C-Type Lectin Receptor (CLR), Toll-like receptor (TLR), Nod-like receptor (NLR), Retinoic acid-inducible gene-I-like receptor (RLR), which play a role in innate immunity to IAV infection, and the pyrin and hematopoietic interferon-inducible nuclear (PYHIN) domain protein. Here, we discuss the role of PRRs in cellular infectivity of IAV and highlight the recent progress.
\end{abstract}

Key words: IAV; influenza A virus; innate immunity; receptors; PRRs.

J Infect Dev Ctries 2021; 15(1):1-8.. doi:10.3855/jidc.13258

(Received 13 June 2020 - Accepted 26 November 2020)

Copyright (C) 2021 Almatrrouk et al. This is an open-access article distributed under the Creative Commons Attribution License, which permits unrestricted use, distribution, and reproduction in any medium, provided the original work is properly cited.

\section{Introduction}

Influenza virus of the family Orthomyxoviridae causes the flu, which is an infection of the respiratory tract that has been reported over two millennia ago [1]. Influenza viruses are classified into three genera based on the antigenic differences in their nucleoprotein and matrix protein, of which only the influenza A Virus (IAV) is known to cause pandemics. IAV causes influenza in birds and a few other species of mammals like humans and pigs. Its wide host range allows it to cause pandemics like the 1918 Spanish flu. IAV annually infects 3-5 million people by direct contact with infected humans and fomites. The disease also spreads due to inhalation of the aerosols that are expelled by infected humans when they cough or sneeze. It is characterized by an assortment of direct and indirect pathological effects [2]. The decimation of the infected respiratory cells, damage to the respiratory epithelium, and the immunological responses that cause pneumonia and general discomforts like body ache, coughing, sneezing, high fever, sore throat, rhinorrhoea, myalgia, and fatigue are considered as direct effects [3]. While the secondary bacterial infection due to tissue damage and the worsening of other diseases like cardiovascular diseases and diabetes are considered as indirect effects [4]. IAV infection claimed an emphatically enormous number of lives during flu seasons of the last century worldwide [5]. It commonly affects children, adolescents, elderly people, and immunocompromised humans. IAV has several subtypes, labelled as per the two proteins on the surface of the viral envelope. These proteins are haemagglutinin (HA), which causes red blood cells to agglutinate, and neuraminidase (NA), which is an enzyme that breaks the glycosidic bonds of neuraminic acid. Both proteins are essential for the entry and exit of virus particles at the plasma membrane of the target cell [6]. Currently, there are 18 known variations of HA and 11 of NA, theoretically allowing 198 different combinations [7]. Famous combinations include H1N1 (1918 Spanish flu, 1977 Russian Flu, 2009 pandemic flu), H3N2 (1968 Hong Kong flu) and H2N2 (1957 Asian flu) [8]. 


\section{Influenza A virus gene products and pathogenesis}

IAV genome consists of eight segments. The segmented nature allows a range of variabilities in antigens that can be associated with the antigenic shift, which takes place when viral recombination occurs in a cell that may be co-infected with two or more viruses. A good example of this is the 2009 flu virus, which was found to be a "quadruple reassortant" virus $[9,10]$. IAV produced proteins, their function and their respective RNA segments are illustrated in Table 1.

Human infection by influenza virus is achieved through oral or nasal cavities where the viral NA protein helps the virus permeate the mucus that covers the respiratory epithelium by cleaving the sialic acids that are found in the respiratory tract mucous. If not for this NA protein, the virion would be trapped in the mucous, preventing it from reaching the host cell $[11,12]$. After successfully penetrating the mucous layer, the virus attaches to and invades the respiratory epithelial cells. The attachment is mediated by the HA protein, which is the primary IAV antigen to which the host's immune system responds by inducing a neutralizing antibody response. The HA protein is a trimeric glycoprotein on the virus surface, with an inherent specificity for $\alpha-2,6$ linked sialic acid on host cell surfaces $[13,14]$. Once replication in these cells becomes productive, the virus spreads to both non-immune and immune cells in the respiratory tract [15].

Years of co-evolution have helped the virus develop strategies to evade the host immune system. Viral matrix protein, M2, is known to play a role in autophagy by blocking auto-phagosome maturation, preventing fusion with the lysosome and significantly affecting host cell apoptosis [16]. The virus is also known to prevent the activation of interferon-inducible dsRNA- dependent protein kinase by binding to dsRNA using the non-structural protein 1 (NS1) $[17,18]$. The NS1 protein is also known to inhibit NFKB by physically interacting with the $\mathrm{C}$-terminal effector domain of $\mathrm{I} \kappa \mathrm{B}$ kinase (IKK) [19]. NS1 has been shown to affect the phosphorylation function in both the cytoplasm and nucleus of IKK $\alpha / \mathrm{IKK} \beta$. It stops the translocation of $\mathrm{NF \kappa B}$ into the nucleus by blocking IKK $\beta$-mediated phosphorylation and degradation of $\mathrm{I} \kappa \mathrm{B} \alpha$ in the classical pathway of NF- $\mathrm{KB}$ activating signalling. It suppresses IKK $\alpha$-mediated processing of p100 to p52 in the alternative pathway [19]. Another viral protein, PB1-F2, has been shown to have pleiotropic effects [20]. The protein was reported to cause apoptosis in immune cells, thus affecting efficient viral clearance [21]. This is achieved by a PB1-F2 mediated bridging of mitochondrial apoptotic mediators ANT3 and VDAC1, which mediates mitochondrial permeabilization, followed by a cytochrome $\mathrm{C}$ release, leading to apoptosis [22]. PB1-F2 increases the chances for the development of secondary bacterial pneumonia, which is a serious life-threatening complication, causing severe lung damage, high inflammatory response, hypertyrosinemia and elevated bacterial loads $[20,23,24]$. This may be achieved by PB1-F2 interacting with $\operatorname{IKK} \beta$, which is known to suppress IFN $\gamma$ signalling in macrophages by inhibiting STAT1 activation [25]. It has also been shown that PB1-F2 inhibits NFKB binding to the DNA. However, the ability of PB1-F2 to modulate NFKB signalling pathway does not correlate to its ability to interact with IKK $\beta$, suggesting that it may recruit other proteins to interact with IKK $\beta$. Hence, all cytokines expressed under the control of NFKB are potentially susceptible to modulation through PB1-F2 [26].

Table 1. Influenza proteins and their functions.

\begin{tabular}{|c|c|c|}
\hline Protein & $\begin{array}{c}\text { RNA } \\
\text { Segment }\end{array}$ & Function \\
\hline RNA polymerase subunit (PB2) & 1 & RNA-dependent RNA polymerase \\
\hline $\begin{array}{l}\text { RNA polymerase subunit }(\mathbf{P B 1}) \text { or } \mathbf{P B 1}- \\
\text { F2 protein }\end{array}$ & 2 & RNA-dependent RNA polymerase \\
\hline RNA polymerase subunit $(\mathbf{P A})$ & 3 & $\begin{array}{l}\text { PA is involved in the assembly of functional viral RNA polymerase complexes } \\
\text { from their active intermediates }\end{array}$ \\
\hline Hemagglutinin (HA = HA1 and HA2) & 4 & $\begin{array}{l}\text { HA1 mediates binding to sialic acid of target cells by the virion. HA2 mediates } \\
\text { entry of the viral genome into the target cell by acting as the fusion peptide. }\end{array}$ \\
\hline Nucleoprotein (NP) & 5 & Encapsulates RNA and provides species specificity. \\
\hline Neuraminidase (NA) & 6 & $\begin{array}{l}\text { Remove sialic acid from glycoproteins. Prevents trapping in mucus on entry and } \\
\text { aggregation on cells during exit. }\end{array}$ \\
\hline Two matrix proteins $(\mathbf{M}=\mathbf{M} 1$ and $\mathbf{M} 2)$ & 7 & $\begin{array}{l}\text { M1 mediates the encapsidation of RNA-nucleoprotein cores into the membrane } \\
\text { envelope and assists in virion assembly and egress. M } 2 \text { facilitates budding of } \\
\text { mature virions. }\end{array}$ \\
\hline Non-structural proteins (NS1 and NEP) & 8 & $\begin{array}{l}\text { NS1 suppresses interferon response. NEP mediates export of vRNP complexes } \\
\text { from nucleus }\end{array}$ \\
\hline
\end{tabular}


Viruses exhibit certain pathogen-associated molecular patterns (PAMPs), like double-stranded RNA, that are usually not found in the hosts [27]. These PAMPs are then recognized by certain receptors known as pattern recognition receptors (PRRs) [28]. These PRRs are subdivided according to their ligand specificity, function, localization, and/or evolutionary relationships. The main receptor to recognize the single-stranded RNA and transcriptional intermediates in the host cell is the retinoic acid-inducible gene-I protein (RIG-I). Toll-like receptors (TLRs) are another group of PRR that detect pathogens near the cells and in endosomes and lysosomes. Other PRRs like nucleotide oligomerization and binding domain (NOD)-like receptor, have been known to activate during an IAV infection [29]. These PRRs trigger a rapid, nonspecific innate immune response, which mostly culminates in the elimination of the virus from the host. In this article, we will focus mainly on the role of virus-sensing receptors in cellular infectivity of IAV.

\section{Virus sensing receptors}

Five major groups of PRR have currently been identified, namely retinoic acid-inducible gene-I (RIGI)-like receptors (RLRs), C-type lectin receptors (CLRs), Toll-like receptors (TLRs), NOD-like receptors (NLRs) and the PYHIN domain containing family, including AIM2 [30]. The first four group are discussed below.

\section{RIG-I-like receptors (RLRs)}

RLRs consist of three members that have been identified in humans and mice, the retinoic acidinducible gene-I (RIG-I), melanoma differentiationassociated gene 5 (MDA5), and laboratory of genetics and physiology 2 (LGP2) [31]. RLRs are exclusively cytosolic PRRs. They play an important role as RNAsensing PRRs belonging to the RNA helicase family [32]. Studies have demonstrated that RIG-I enters antiviral stress granules where viral RNA and interferon-stimulated gene (ISG) products like serine/threonine-specific protein kinase co-localize [33]. RIG-I recognizes virus-associated RNA species, like 5'-triphosphate single-stranded RNA and its transcriptional intermediates, with its helicase domain [34]. It is expressed in a variety of cells like macrophages, fibroblasts, myeloid dendritic cells, and epithelial cells $[15,35]$. In addition to the RNA helicase domain, RIG-I contains two N-terminal caspase activation and recruitment domains (CARDs) [36]. On recognition of viral RNA, RIG-I exposes its CARDs, which are controlled by dephosphorylation or ubiquitination by E3 ligases. On activation, RIG-I interacts with the adaptor molecule mitochondrial antiviral signalling (MAVS) on the outer membrane of the mitochondria (Figure 1). This promoter leads to phosphorylation of interferon regulatory factor IRF3 and activates nuclear factor kappa-light-chain-enhancer of activated B cells NF- $\mathrm{BB}$; thus, helps in inducing type I interferons, pro-inflammatory cytokines, and chemokines [37]. RIG-I has also been proposed as a molecular adjuvant for the flu vaccine as it was shown to reduce the antigen requirement by 10 - to 100 -fold [38]. Studies have also established that the individual deletion of either RIG-I or MAVS coding genes did not change survival or innate responses in vivo after IAV infection in mice, but caused an increased risk of infection $[39,40]$.

\section{C-Type Lectin Receptors (CLRs)}

Dendritic cell-specific intercellular adhesion molecule-3-grabbing nonintegrin (DC-SIGN) is a Ctype lectin, mainly present at the surface of dendritic cells (DC) [41]. Studies have shown that the lectinmediated recognition of mannose-rich glycans on IAV

Figure 1. RLR signalling overview.

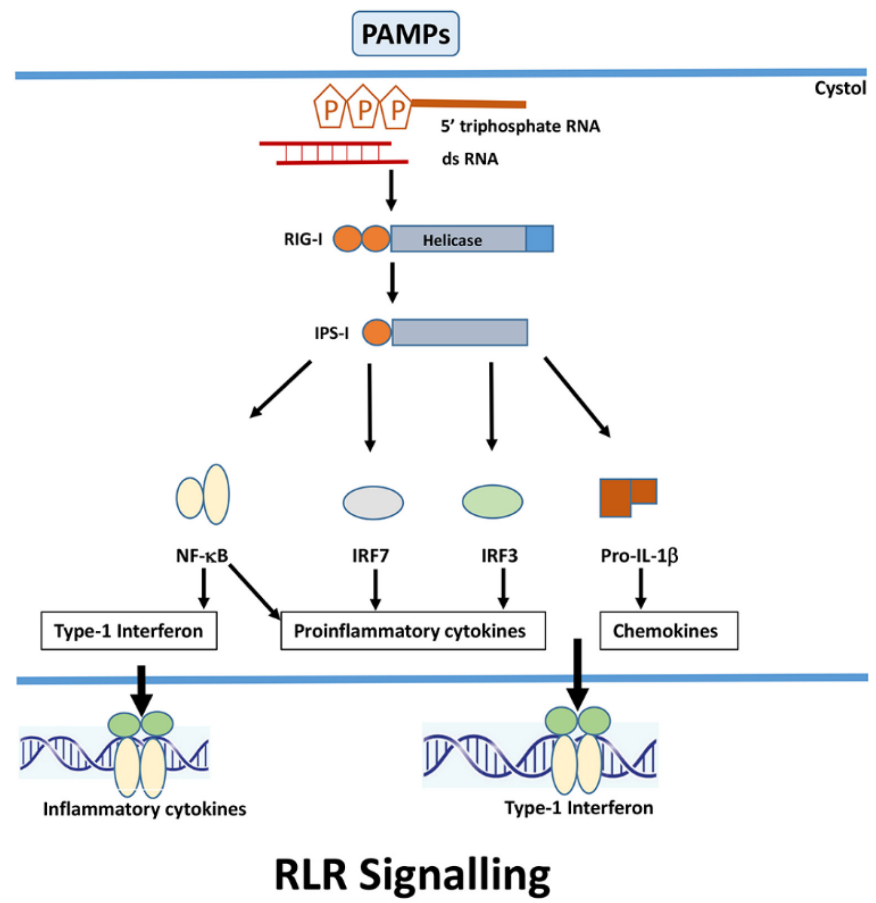

Virus infection is recognized by the cytoplasmic sensor Retinoic acid inducible gene like receptors (RIG1) which binds to viral doublestranded RNA and triggers two signaling branches via mitochondrial adaptor IPS1. Retinoic acid inducible gene like receptors (RIG1) recognizes viral RNA and signals IFN promoter stimulator-1 (IPS-1), which leads to phosphorylation of IRF7/3 and NF- $\mathrm{KB}$, and thus helps in inducing type 1 IFNs, proinflammatory cytokines and chemokines. This contributes to the overall antiviral responses of the host. 
facilitated the infection of the cells by endocytosis in a sialic acid-independent manner [42]. DC-SIGN also acts as an alternative receptor for IAV in addition to sialic acid and the extent of glycosylation of HA mediates the efficiency of DC-SIGN recognition [43]. Besides, DC-SIGN blocking antibodies helps in reducing cellular infectivity [44]. DC-SIGN has a human homologous protein in mouse which is known as SIGN-R1 and is expressed in macrophages of spleen and lymph nodes. This SIGN-R1 is also reported to interact with IAV strain A/PR/8/34(PR8) by DCs of lymph node both in vitro and in vivo, thus making this receptor essential for humoral immunity [45]. Additional CLRs, such as MGL and MMR, also interact with IAV and are salicylic acid (SA)-independent but correlate with the different HA glycosylation levels of a few IAV strains [46]. Figure 2 sheds light on some of these interactions.

\section{Toll-Like Receptors (TLRs)}

Among the PRRs, the Toll receptor in drosophila was first shown to be necessary for protection against fungal infection [47]. Subsequently, the ten mammalian homologues of the TLRs were described for humans [48]. TLRs are important key sensors belonging to PAMPs. TLR3, TLR7, TLR8, and TLR9 recognize nucleic acid of intracellular or endosomal origin and TLR1, TLR2, TLR4 and TLR6 which are present on

Figure 3. TLR signalling overview.

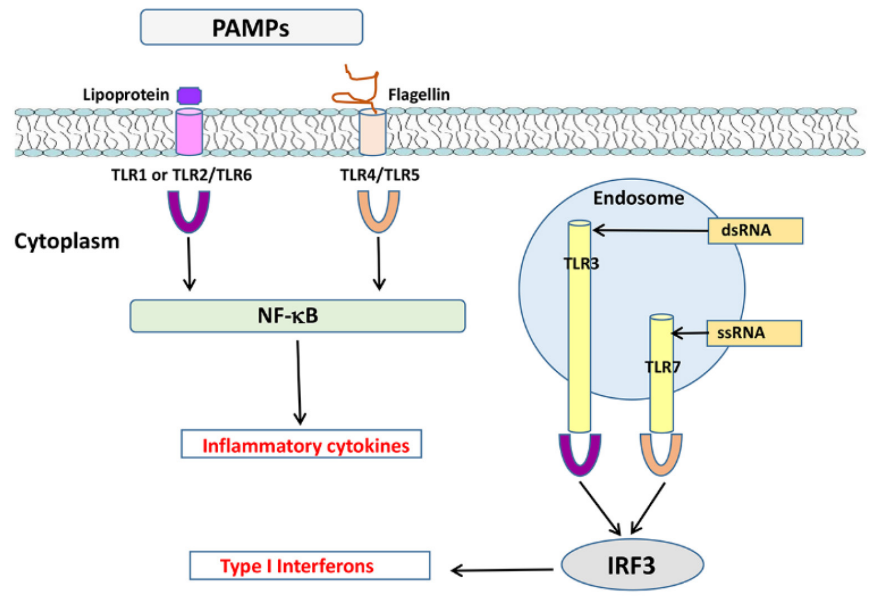

TLR Signalling

MyD88-dependent signalling pathway is used by all TLRs except TLR7 and TLR3. TLR7, which binds to ssRNA, and TLR3, which binds to dsRNA, activate the transcription factor, interferon regulatory factor (IRF3) followed by activation of type 1 interferon. Other TLRs, present on cell surface, trigger antiviral innate immune response by producing inflammatory cytokines.
Figure 2. CLR signalling overview.

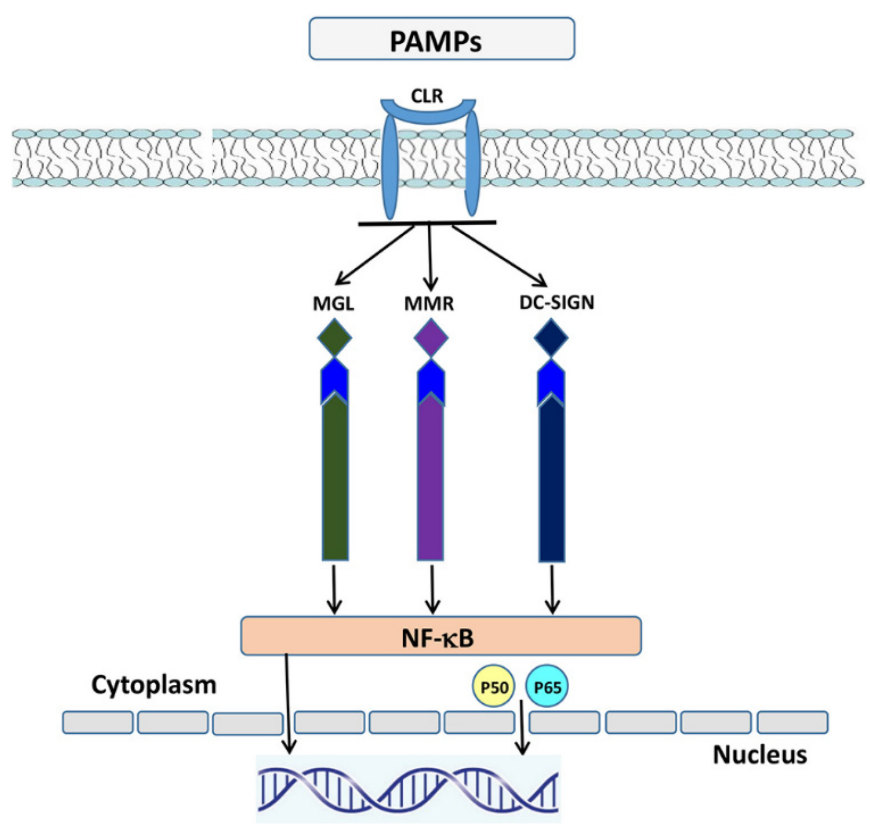

\section{CLR Signalling}

Macrophage galactose-type lectin (MGL), macrophage-mannose receptor (MMR) and dendritic cell specific intercellular adhesion molecule 3 grabbing non integrin (DC-SIGN) augment activation of NF$\kappa \mathrm{B}$ with $\mathrm{P} 50$ and $\mathrm{P} 65$ subunits. The activation of NF- $\mathrm{\kappa B}$ plays a critical role in the induction of innate immune and inflammatory responses as it leads to subsequent secretion of proinflammatory cytokines.

cell surface detect the envelope glycoproteins and lipoproteins. These intracellular TLRs appear to be sensors of foreign nucleic acids and trigger an antiviral innate immune response by producing type 1 interferon and inflammatory cytokines [49]. TLRs, in cooperation with other PRRs such as NLRs and RLRs, induce innate immunity against IAV [50]. Figure 3 shows that the binding of TLRs activates the transcription factor, interferon regulatory factor (IRF3), followed by activation of type 1 interferon. Studies have shown that most TLRs recognize the double-stranded RNA (dsRNA) while TLR7 and TLR8 bind to singlestranded RNA (ssRNA) in the endosomes, thus helping to recognize IAV [51,52]. The TLRs which are activated by IAV infection are briefly discussed below.

$\underline{\text { TLR3 }}$

TLR3 recognizes RNA viruses through surface receptors. They are expressed in low levels in macrophages and primary respiratory cells but at the same time remained absent in dendritic cells, monocytes, and neutrophils. They detect RNA that is associated with infected cells [15]. During the 
replication of IAV, dsRNA is not generated due to the action of RNA helicase DDX39B. Consequently, it is important to identify the ligand for TLR3 within the influenza-infected cells [15]. Intranasal treatment of mice with poly I:C, a TLR3 agonist, provided a high level of protection against lethal challenge with a highly pathogenic avian influenza virus (H5N1) and showed enhancement of inflammatory reaction and CD8+ T cell response in viral clearance. This suggests that TLR3triggered innate response inhibits viral spread [53,54].

\section{TLR7 and TLR8}

Both TLR7 and TLR8 recognize the viral genome of various viruses such as influenza viruses, flaviviruses, coxsackie B virus, HIV-1, and vesicular stomatitis virus. TLR8 is mostly expressed in monocytes, macrophages, and myeloid DCs whereas TLR7 is primarily expressed in DCs and, to some extent, in B cells, monocytes, and macrophages. TLR8 and, to a lesser extent, TLR7 recognizes the GU-rich and AU-rich ssRNA sequences of influenza viruses [55]. Once the replication begins, the viral RNA is released into endosomes where TLR7 and TLR8 reside. Interaction of ssRNA and TLR7/TLR8 triggers the recruitment of a protein involved in signaling within immune cells called myeloid differentiation primary response 88 protein (MyD88), which leads to the activation of NF- $\mathrm{kB}$ and other transcription factors and the production of proinflammatory cytokines and chemokines [56].

Figure 4. NLR signalling overview.
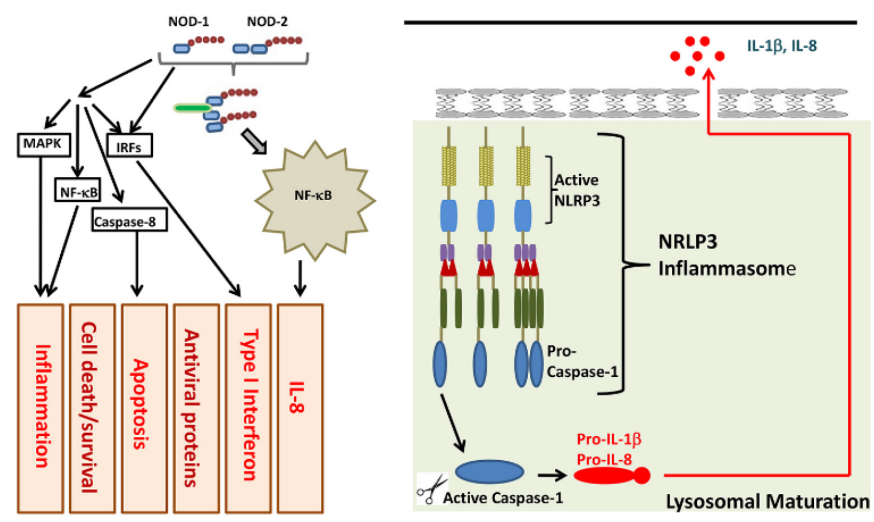

NLR Signalling

Nod like receptor-P3 (NLRP3) induces influenza virus in two steps, namely enhancing the transcription of genes encoding pro-IL-Ib and proIL-18 and NLRP3 (signal 1) and activating NLRP3 inflammasomes (signal 2). This activates NF-KB and MAPK signaling via the indicated proteins leading to the transcriptional upregulation of a variety of proinflammatory cytokines and antimicrobial peptides.

\section{$\underline{\text { TLR4 }}$}

TLR4 is usually expressed by myeloid cells and weakly expressed on the surface of epithelial cells. Although the ligand for TLR4 is not known in the case of IAV, the DDX21-TRIF-S100A9-TLR4-MyD88 signalling network is triggered by the DAMP molecule, S100A9, regulating inflammation during infection [57]. This molecule is released in IAV-infected lungs and helps in inducing exaggerating proinflammatory response, cell-death, and virus pathogenesis following lethal infection [54]. Additional studies showed that the treatment of mice with the TLR4 antagonist, Eritoran, was found to protect from lethal IAV infection by alleviating lung pathology, clinical symptoms, cytokine, and oxidized phospholipid expression, as well as by controlling viral loads [58].

\section{Nucleotide-binding oligomerization domain-like receptors (NLRS)}

NLRs are intracellular sensors of PAMPs that form a multiprotein inflammasome complex consisting of NLRP, the adaptor ASC, and procaspase. They also help in triggering several signalling pathways including MAPK, NF-kB, and MAVS-IRF3, which help in the production of IL-6, TNF- $\alpha$, pro- IL-1 $\beta / \mathrm{IL}-18$, and also type I interferons [59]. NACHT, LRR and PYD domains-containing protein 3 (NLRP3) are known to be activated by membrane damage, inflammation or stress such as infection with pathogens [60]. These receptors are known to cooperate with TLRs to regulate inflammatory and apoptotic responses. Studies have shown that NLRP3, induces IAV in two steps, namely enhancing the transcription of genes encoding pro-IL$1 \beta$ and pro-IL-18 and NLRP3 (signal 1 ) and activating NLRP3 inflammasome (signal 2) as seen in Figure 4 [61]. The ssRNA of the virus, the proton flux by viral M2 in the trans-Golgi network and the aggregation of PB1-F2 in the lysosome of lipopolysaccharide primed macrophages are known activators of NLRP3 inflammasome $[58,62,63]$. The NLRP3 inflammasomes complex was found essential for reducing the viral load in the later stages of infection, suggesting that NLRP3inflammasome induced inflammatory response and mediates the protective immunity to IAV infection, possibly via adaptive immune responses [64]. NLRC2 (or NOD2) is believed to recognize the viral genomic ssRNA which assists the recruitment of MAVS adaptor protein in activating IRF3-mediated type I interferon production in DCs in response to IAV. NOD2 and NLRX1 are also found to negatively regulate the NLRP3 and RIG-induced inflammatory response to lethal doses of IAV, respectively, and to control the 
immunopathology of IAV $[61,64]$. These findings suggest that NLRs execute a differential role in response to IAV infection.

\section{Conclusions}

Our knowledge of innate immune response and the possibly damaging role of innate immunity in the pathogenesis of influenza remain preliminary. The past ten years have expanded our understanding of innate sensing and response to IAV infection. The innate immunity plays an important role upon infection with IAV in rapid control, particularly natural killer cells (NK) which possess potent antiviral activity [65]. This also helps in initiation of adaptive immunity, particularly the production of HA and NA specific antibodies [66].

The role of PRRs in the recognition and activation of signalling pathways, which ultimately results in a pro-inflammatory innate immune response has been discussed in various studies [30,48,58]. PRRs recognize unique molecular signatures which are nonself and possess evolutionarily conserved structures and trigger innate immune response, including the production of pro-inflammatory cytokines and type 1 interferons. Identification of immunological receptors has helped in the development of the concept of pattern recognition and thus has significantly changed the perception of the innate immune system. PRRs play an important part in cellular injury and in recognizing immunological stress. Perception of various endogenous danger signals has put PRRs in a central position in the regulation of immunity and other aspects of cellular physiology and is regarded as sensors of both microbe-associated molecular pattern and danger associated molecular pattern. In this review, we examined available data on the inflammatory response of PRRs which coordinates proinflammatory cytokines (TNF, IL-1, IL-6), regulates cell death, helps in modifying vascular permeability, and induces the production of acute phase proteins as useful markers of inflammation.

\section{Acknowledgements}

This work is part of a project funded by the Biotechnology program of the King Abdulaziz City for Science and Technology (14-MED258-20) and approved by the Research Advisory Council of the King Faisal Specialist Hospital and Research Centre, Riyadh (2150031).

\section{Authors' contributions}

SA, IS, and MNAA performed literature review and prepared the manuscript. SMA, AAAQ and MNAA edited and provided comments. All authors contributed to the design and preparation of this scientific review.

\section{References}

1. Martin PMV, Martin-Granel E (2006) 2,500-year evolution of the term epidemic. Emerg Infect Dis 12: 976-980.

2. Gounder AP, Boon ACM (2019) Influenza pathogenesis: The effect of host factors on severity of disease. J Immunol 202: 341-350.

3. Clohisey S, Baillie JK (2019) Host susceptibility to severe influenza A virus infection. Crit Care 23: 303-313.

4. Rothberg MB, Haessler SD (2010) Complications of seasonal and pandemic influenza. Crit Care Med 38 Suppl 4: 91-97.

5. Lozano R, Naghavi M, Foreman K, Lim S, Shibuya K, Aboyans V, Abraham J, Adair T, Aggarwal R, Ahn SY, Alvarado M, Anderson HR, Anderson LM, Andrews KG, Atkinson C, Baddour LM, Barker-Collo S, Bartels DH, Bell ML, Benjamin EJ, Bennett D, Bhalla K, Bikbov B, Bin Abdulhak A, Birbeck G, Blyth F, Bolliger I, Boufous S, Bucello C, Burch M, Burney P, Carapetis J, Chen H, Chou D, Chugh SS, Coffeng LE, Colan SD, Colquhoun S, Colson KE, Condon J, Connor MD, Cooper LT, Corriere M, Cortinovis M, de Vaccaro KC, Couser W, Cowie BC, Criqui MH, Cross M, Dabhadkar KC, Dahodwala N, De Leo D, Degenhardt L, Delossantos A, Denenberg J, Des Jarlais DC, Dharmaratne SD, Dorsey ER, Driscoll T, Duber H, Ebel B, Erwin PJ, Espindola P, Ezzati M, Feigin V, Flaxman AD, Forouzanfar MH, Fowkes FG, Franklin R, Fransen M, Freeman MK, Gabriel SE, Gakidou E, Gaspari F, Gillum RF, Gonzalez-Medina D, Halasa YA, Haring D, Harrison JE, Havmoeller R, Hay RJ, Hoen B, Hotez PJ, Hoy D, Jacobsen KH, James SL, Jasrasaria R, Jayaraman S, Johns N, Karthikeyan G, Kassebaum N, Keren A, Khoo JP, Knowlton LM, Kobusingye O, Koranteng A, Krishnamurthi R, Lipnick M, Lipshultz SE, Ohno SL, Mabweijano J, MacIntyre MF, Mallinger L, March L, Marks GB, Marks R, Matsumori A, Matzopoulos R, Mayosi BM, McAnulty JH, McDermott MM, McGrath J, Mensah GA, Merriman TR, Michaud C, Miller M, Miller TR, Mock C, Mocumbi AO, Mokdad AA, Moran A, Mulholland K, Nair MN, Naldi L, Narayan KM, Nasseri K, Norman P, O'Donnell M, Omer SB, Ortblad K, Osborne R, Ozgediz D, Pahari B, Pandian JD, Rivero AP, Padilla RP, Perez-Ruiz F, Perico N, Phillips D, Pierce K, Pope CA 3rd, Porrini E, Pourmalek F, Raju M, Ranganathan D, Rehm JT, Rein DB, Remuzzi G, Rivara FP, Roberts T, De León FR, Rosenfeld LC, Rushton L, Sacco RL, Salomon JA, Sampson U, Sanman E, Schwebel DC, Segui-Gomez M, Shepard DS, Singh D, Singleton J, Sliwa K, Smith E, Steer A, Taylor JA, Thomas B, Tleyjeh IM, Towbin JA, Truelsen $\mathrm{T}$, Undurraga EA, Venketasubramanian $\mathrm{N}$, Vijayakumar L, Vos T, Wagner GR, Wang M, Wang W, Watt K, Weinstock MA, Weintraub R, Wilkinson JD, Woolf AD, Wulf S, Yeh PH, Yip P, Zabetian A, Zheng ZJ, Lopez AD, Murray CJ, AlMazroa MA, Memish ZA (2012) Global and regional mortality from 235 causes of death for 20 age groups in 1990 and 2010: a systematic analysis for the Global Burden of Disease Study 2010. Lancet. 380: 2095-2128.

6. Samji T (2009) Influenza A: understanding the viral life cycle. Yale J Biol Med 82: 153-159.

7. Tong S, Zhu X, Li Y, Shi M, Zhang J, Bourgeois M, Yang H, Chen X, Recuenco S, Gomez J, Chen LM, Johnson A, Tao Y, Dreyfus C, Yu W, McBride R, Carney PJ, Gilbert AT, Chang J, Guo Z, Davis CT, Paulson JC, Stevens J, Rupprecht CE, 
Holmes EC, Wilson IA, Donis RO (2013) New world bats harbor diverse influenza A viruses. PLoS Pathog 9: e1003657.

8. Potter CW (2001) A history of influenza. J Appl Microbiol 91: 572-579.

9. Centers for Disease Control and Prevention (2009) Origin of 2009 H1N1 flu (swine flu): Questions and answers. Available at:

https://www.cdc.gov/h1n1flu/information_h1n1_virus_qa.htm , 2009. Accessed: 04 June 2020.

10. Qu Y, Zhang R, Cui P, Song G, Duan Z, Lei F (2011) Evolutionary genomics of the pandemic $2009 \mathrm{H} 1 \mathrm{~N} 1$ influenza viruses (pH1N1v). Virol J 8: 250.

11. Matrosovich MN, Matrosovich TY, Gray T, Roberts NA, Klenk HD (2004) Neuraminidase is important for the initiation of influenza virus infection in human airway epithelium. J Virol 78: 12665-12667.

12. Shtyrya YA, Mochalova LV, Bovin NV (2009) Influenza virus neuraminidase: structure and function. Acta Naturae 1: 26-32.

13. Sun X, Whittaker GR (2013) Entry of influenza virus. Adv Exp Med Biol 790: 72-82

14. Duo D, Revol R, Östbye H, Wang H, Daniels R (2018) Influenza A virus cell entry, replication, virion assembly and movement. Front Immunol 9: 1581.

15. Iwasaki A, Pillai PS (2014) Innate immunity to influenza virus infection. Nat Rev Immunol 14: 315-328.

16. Gannagé M, Dormann D, Albrecht R, Dengjel J, Torossi T, Rämer PC, Lee M, Strowig T, Arrey F, Conenello G, Pypaert M, Andersen J, García-Sastre A, Münz C (2009) Matrix protein 2 of influenza A virus blocks autophagosome fusion with lysosomes. Cell Host Microbe 6: 367-380.

17. Lu Y, Wambach M, Katze MG, Krug RM (1995) Binding of the influenza virus NS1 protein to double-stranded RNA inhibits the activation of the protein kinase that phosphorylates the e1F-2 translation initiation. Virology. 214: 222-228.

18. Tan SL, Katze MG (1998) Biochemical and genetic evidence for complex formation between the influenza A virus NS1 protein and the interferon-induced PKR protein kinase. J Interferon Cytokine Res 18: 757-766.

19. Gao S, Song L, Li J, Zhang Z, Peng H, Jiang W, Wang Q, Kang T, Chen S, Huang W (2012) Influenza A virus-encoded NS1 virulence factor protein inhibits innate immune response by targeting IKK. Cell Microbiol 14: 1849-1866.

20. Krumbholz A, Philipps A, Oehring H, Schwarzer K, Eitner A, Wutzler P, Zell R (2010) Current knowledge on PB1-F2 of influenza A viruses. Med Microbiol Immunol. 200: 69-75.

21. Chen W, Calvo PA, Malide D, Gibbs J, Schubert U, Bacik I, Basta S, O'Neill R, Schickli J, Palese P, Henklein P, Bennink JR, Yewdell JW (2001) A novel influenza A virus mitochondrial protein that induces cell death. Nat Med 7: 13061312.

22. Zamarin D, García-Sastre A, Xiao X, Wang R, Palese P (2005) Influenza virus $\mathrm{PB} 1-\mathrm{F} 2$ protein induces cell death through mitochondrial ANT3 and VDAC1. PLoS Pathog 1: 4

23. Sethi S (2002) Bacterial pneumonia. Managing a deadly complication of influenza in older adults with comorbid disease. Geriatrics 57: 56-61.

24. McAuley JL, Hornung F, Boyd KL, Smith AM, McKeon R, Bennink J, Yewdell JW, McCullers JA (2007) Expression of the 1918 influenza A virus PB1-F2 enhances the pathogenesis of viral and secondary bacterial pneumonia. Cell Host Microbe 2: $240-249$.

25. Fong CHY, Bebien M, Didierlaurent A, Nebauer R, Hussell T, Broide D, Karin M, Lawrence T (2008) An antiinflammatory role for IKKbeta through the inhibition of "classical" macrophage activation. J Exp Med 205: 1269-1276.

26. Reis AL, McCauley JW (2013) The influenza virus protein PB1-F2 interacts with IKK $\beta$ and modulates NF- $\kappa B$ signalling. PLoS One 8: e63852.

27. Amarante-Mendes GP, Adjemian S, Branco LM, Zanetti LC, Weinlich R, Bortoluci KR (2018) Pattern recognition receptors and the host cell death molecular machinery. Front Immunol 9: 2379.

28. Chen L, Deng H, Cui H, Fang J, Zuo Z, Deng J, Li Y, Wang $X$, Zhao L (2017) Inflammatory responses and inflammationassociated diseases in organs. Oncotarget 9: 7204-7218.

29. Pang IK, Iwasaki A (2011) Inflammasomes as mediators of immunity against influenza virus. Trends Immunol 32: 34-41.

30. Takeuchi O, Akira S (2010) Pattern recognition receptors and inflammation. Cell 140: 805-820.

31. Saito T, Hirai R, Loo Y-M, Owen D, Johnson CL, Sinha SC, Akira S, Fujita T, Gale M Jr (2007) Regulation of innate antiviral defenses through a shared repressor domain in RIG-I and LGP-2. Proc Natl Acad Sci USA 104: 582-587. doi: 10.1073/pnas.0606699104.

32. Onomoto K, Jogi M, Yoo JS, Narita R, Morimoto S, Takemura A, Sambhara S, Kawaguchi A, Osari S, Nagata K, Matsumiya T, Namiki H, Yoneyama M, Fujita T (2012) Critical role of an antiviral stress granule containing RIG-I and PKR in viral detection and innate immunity. PLoS One 7: e43031.

33. Oh SW, Onomoto K, Wakimoto M, Onoguchi K, Ishidate F, Fujiwara T, Yoneyama M, Kato H, Fujita T (2016) Leadercontaining uncapped viral transcript activates RIG-I in antiviral stress granules. PLoS Pathog 10: e1005444.

34. Kell AM, Gale M Jr (2015) RIG-I in RNA virus recognition. Virology. 479-480: 110-121.

35. Kato H, Sato S, Yoneyama M, Yamamoto M, Uematsu S, Matsui K, Tsujimura T, Takeda K, Fujita T, Takeuchi O, Akira S (2005) Cell type-specific involvement of RIG-1 in antiviral response. Immunity. 23: 19-28.

36. Kolakofsky D, Kowalinski E, Cusack S (2012) A structurebased model of RIG-I activation. RNA 18: 2118-2127.

37. Loo YM, Gale M Jr (2011) Immune signaling by RIG-I-like receptors. Immunity. 34: 680-692.

38. Kulkarni RR, Rasheed MA, Bhaumik SK, Ranjan P, Cao W, Davis C, Marisetti K, Thomas S, Gangappa S, Sambhara S, Murali-Krishna K (2014) Activation of the RIG I pathway during influenza vaccination enhances the germinal center reaction, promotes $\mathrm{T}$ follicular helper cell induction, and provides a dose-sparing effect and protective immunity. J Virol 88: 13990-14001.

39. Kato H, Takeuchi O, Sato S, Yoneyama M, Yamamoto M, Matsui K, Uematsu S, Jung A, Kawai T, Ishii KJ, Yamaguchi O, Otsu K, Tsujimura T, Koh CS, Reis e Sousa C, Matsuura Y, Fujita T, Akira S (2006) Differential role of MDA5 and RIG-I helicases in the recognition of RNA viruses. Nature. 441: 101105 .

40. Jørgensen SE, Christiansen M, Ryø LB, Gad HH, Gjedsted J, Staeheli P, Mikkelsen JG, Storgaard M, Hartmann R, Mogensen TH (2018) Defective RNA sensing by RIG-I in severe influenza virus infection. Clin Exp Immunol. 192: 366376.

41. Collin M, McGovern N, Haniffa M (2013) Human dendritic cell subsets. Immunology. 140: 22-30.

42. Ng WC, Londrigan SL, Nasr N, Cunningham AL, Turville S, Brooks AG, Reading PC (2015) The C-type lectin langerin 
functions as a receptor for attachment and infectious entry of influenza A virus. J Virol 90: 206-221.

43. Wang SF, Huang JC, Lee YM, Liu SJ, Chan YJ, Chau YP, Chong P, Chen YM (2008) DC-SIGN mediates avian H5N1 influenza virus infection in cis and in trans. Biochem Biophys Res Commun 373: 561-566.

44. Hillaire ML, Nieuwkoop NJ, Boon AC, de Mutsert G, Vogelzang-van Trierum SE, Fouchier RA, Osterhaus AD, Rimmelzwaan GF (2013) Binding of DC-SIGN to the hemagglutinin of influenza A viruses supports virus replication in DC-SIGN expressing cells. PLoS One. 8: e56164.

45. Gonzalez SF, Lukacs-Kornek V, Kuligowski MP, Pitcher LA, Degn SE, Kim YA, Cloninger MJ, Martinez-Pomares L, Gordon S, Turley SJ, Carroll MC (2010) Capture of influenza by medullary dendritic cells via SIGN-R1 is essential for humoral immunity in draining lymph nodes. Nat Immunol 11: 427-434.

46. de Geus ED, Vervelde L (2013) Regulation of macrophage and dendritic cell function by pathogens and through immunomodulation in the avian mucosa. Dev Comp Immunol 41: 341-351.

47. Lemaitre B, Nicolas E, Michaut L, Reichhart J-M, Hoffmann JA (2012) Pillars article: The dorsoventral regulatory gene cassette spätzle/Toll/cactus controls the potent antifungal response in Drosophila adults. Cell. 1996. 86: 973-983. J Immunol. 188(11):5210-5220.

48. Kawai T, Akira S (2011) Toll-like receptors and their crosstalk with other innate receptors in infection and immunity. Immunity 34: 637-650.

49. Ioannidis I, Ye F, McNally B, Willette M, Flaño E (2013) Tolllike receptor expression and induction of type I and type III interferons in primary airway epithelial cells. J Virol 87: 32613270 .

50. Wu S, Metcalf JP, $\mathrm{Wu} \mathrm{W}$ (2011) Innate immune response to influenza virus. Curr Opinion Infect Dis 24: 235-240.

51. Wisskirchen C, Ludersdorfer TH, Müller DA, Moritz E, Pavlovic J (2011) The cellular RNA helicase UAP56 is required for prevention of double-stranded RNA formation during influenza A virus infection. J Virol 85: 8646-8655.

52. Dalpke AH, Helm M (2012) RNA mediated toll-like receptor stimulation in health and disease. RNA Biol 9: 828-842.

53. Takeuchi $O$, Akira $S(2009)$ Innate immunity to virus infection. Immunol Rev 227: 75-86.

54. Pulendran B, Maddur MS (2015) Innate immune sensing and response to influenza. Curr Top Microbiol Immunol 386: 23 71.

55. Patel MC, Shirey KA, Pletneva LM, Boukhvalova MS, Garzino-Demo A, Vogel SN, Blanco JC (2014) Novel drugs targeting toll-like receptors for antiviral therapy. Future Virol 9: 811-829.

56. Akira S, Hemmi H (2003) Recognition of pathogen-associated molecular pattern by TLR family. Immunol Lett 85: 85-95.

57. Tsai SY, Segovia JA, Chang TH, Morris IR, Berton MT, Tessier PA, Tardif MR, Cesaro A, Bose S (2014) DAMP molecule S100A9 acts as a molecular pattern to enhance inflammation during influenza A virus infection: role of DDX21-TRIF-TLR4-MyD88 pathway. PLoS Pathog 10: e1003848.

58. Shirey KA, Lai W, Scott AJ, Lipsky M, Mistry P, Pletneva LM, Karp CL, McAlees J, Gioannini TL, Weiss J, Chen WH, Ernst RK, Rossignol DP, Gusovsky F, Blanco JC, Vogel SN (2013) The TLR4 antagonist Eritoran protects mice from lethal influenza infection. Nature. 497: 498-502.

59. McAuley JL, Tate MD, MacKenzie-Kludas CJ, Pinar A, Zeng W, Stutz A, Latz E, Brown LE, Mansell A (2013) Activation of the NLRP3 inflammasome by IAV virulence protein PB1F2 contributes to severe pathophysiology and disease. PLoS Pathog 9: e1003392.

60. Martinon F, Mayor A, Tschopp T (2009) The inflammasomes: guardians of the body. Ann Rev Immunol 27: 229-265.

61. Lupfer C, Thomas PG, Anand PK (2013) Receptor interacting protein kinase 2-mediated mitophagy regulates inflammasome activation during virus infection. Nat Immunol 14:480-488.

62. Thomas PG, Dash P, Aldridge JR Jr, Ellebedy AH, Reynolds C, Funk AJ, Martin WJ, Lamkanfi M, Webby RJ, Boyd KL, Doherty PC, Kanneganti TD (2009) The intracellular censor NLRP3 mediates key innate and healing responses to influenza A virus via the regulation of caspase-1. Immunity 30: 566-575.

63. Ichinohe T, Pang IK, Iwasaki A (2010) Influenza virus activates inflammasomes via its intracellular M2 ion channel. Nat Immunol 11: 404-410.

64. Allen IC, Moore CB, Schneider M, Lei Y, Davis BK, Scull MA, Gris D, Roney KE, Zimmermann AG, Bowzard JB, Ranjan P, Monroe KM, Pickles RJ, Sambhara S, Ting JP (2011) NLRX1 protein attenuates inflammatory responses to infection by interfering with the RIG-I-MAVS and TRAF6NF- $\kappa \mathrm{B}$ signaling pathways. Immunity 34 : 854-865.

65. Mahmoud AB, Tu MM, Wight A, Zein HS, Rahim MM, Lee SH, Sekhon HS, Brown EG, Makrigiannis AP (2016) Influenza virus targets class I MHC-educated NK cells for Immunoevasion. PloS Pathog 12: e1005446.

66. Lai JC, Karunarathna HM, Wong HH, Peiris JS, Nicholls JM (2019) Neuraminidase activity and specificity of influenza A virus are influenced by haemagglutinin-receptor binding. Emerg Microbes Infect 8: 327-338.

\section{Corresponding author}

Prof. Mohammed N. Al-Ahdal

Department of Infection and Immunity

King Faisal Specialist Hospital and Research Centre

PO Box 3354 (MBC-03), Riyadh 11211, Saudi Arabia

Tel: +966114427867

Fax: +966114424519

E-Mail: profahdal@gmail.com

Conflict of interests: No conflict of interests is declared. 